\title{
Study on Suitability of KOD DNA Polymerase for Enzymatic Production of Artificial Nucleic Acids Using Base/Sugar Modified Nucleoside Triphosphates
}

\section{Masayasu Kuwahara ${ }^{1, *}$, Yuuki Takano ${ }^{1}$, Yuuya Kasahara ${ }^{1}$, Hiroki Nara ${ }^{1}$, Hiroaki Ozaki ${ }^{1}$, Hiroaki Sawai ${ }^{1}$, Akio Sugiyama ${ }^{2}$ and Satoshi Obika ${ }^{3}$}

1 Graduate School of Engineering, Gunma University, 1-5-1 Tenjin-cho, Kiryu, Gunma 376-8515, Japan

2 Tsuruga Institute of Biotechnology, Toyobo Co., Ltd., 10-24 Toyo-cho, Tsuruga, Fukui 914-0047, Japan

3 Graduate School of Pharmaceutical Sciences, Osaka University, Osaka 565-0871, Japan

* Author to whom correspondence should be addressed; E-Mail: kuwahara@chem-bio.gunma-u.ac.jp; Tel.: +81-277-30-1222; Fax: +81-277-30-1222.

Received: 30 September 2010; in revised form: 6 November 2010 / Accepted: 10 November 2010 / Published: 12 November 2010

\begin{abstract}
Recently, $K O D$ and its related DNA polymerases have been used for preparing various modified nucleic acids, including not only base-modified nucleic acids, but also sugar-modified ones, such as bridged/locked nucleic acid (BNA/LNA) which would be promising candidates for nucleic acid drugs. However, thus far, reasons for the effectiveness of $K O D$ DNA polymerase for such purposes have not been clearly elucidated. Therefore, using mutated KOD DNA polymerases, we studied here their catalytic properties upon enzymatic incorporation of nucleotide analogues with base/sugar modifications. Experimental data indicate that their characteristic kinetic properties enabled incorporation of various modified nucleotides. Among those $K O D$ mutants, one achieved efficient successive incorporation of bridged nucleotides with a 2'-ONHCH${ }_{2} \mathrm{CH}_{2}-$ $4^{\prime}$ linkage. In this study, the characteristic kinetic properties of $K O D$ DNA polymerase for modified nucleoside triphosphates were shown, and the effectiveness of genetic engineering in improvement of the enzyme for modified nucleotide polymerization has been demonstrated.
\end{abstract}


Keywords: $K O D$ DNA polymerase; artificial nucleic acids; modified nucleoside triphosphates

\section{Introduction}

To diversify the ability and enhance the nuclease resistance of functional nucleic acids like ribozymes and aptamers [1-4], enzymatic production of various modified nucleic acids has been investigated [5-15]. This is because those functional nucleic acids can be created by a random screening method, which involves enzymatic amplification of selected nucleic acids as a key step. We first demonstrated that KOD Dash DNA polymerase is very suitable for amplifying modified DNA by polymerase chain reaction (PCR) using the C5-substituted thymidine analogue [16]. Until now, many types of DNA polymerases were evaluated, and some of them, e.g. Vent(exo-), Pwo and Phusion HighFidelity, were found to be useful for enzymatic production of artificial nucleic acids. However, a series of experimental results from our laboratories indicated that KOD Dash DNA polymerase was more tolerant than any of the other aforementioned polymerases, not only towards base-modification, but also sugar-modification, and thus would be excellent for this purpose [17-20]. This is further supported by recent reports [21, 22] regarding enzymatic production of bridged/locked nucleic acid (BNA [23, 24]/LNA [25]) using KOD DNA polymerase. Furthermore, KOD DNA polymerase was often reported as the only one working for long PCR with modified nucleoside triphosphates [26, 27].

$K O D$ Dash DNA polymerase is a mixture of wild-type $K O D$ DNA polymerase and KOD(exo-) DNA polymerase having no or less $3^{\prime}, 5^{\prime}$ exonuclease activity. The wild-type $K O D$ DNA polymerase belongs to the evolutional family $\mathrm{B}$, and was originally isolated from the hyperthermophilic archaeon, Pyrococcus kodakaraensis [28]. Here, we have prepared eight KOD mutants (KOD1-8) [29, 30], among which four mutants $(K O D 1-3,8)$ have no or less $3^{\prime}, 5^{\prime}$ exonuclease activity, by genetically engineering $K O D$ DNA polymerase, then assessed and compared the catalytic properties of those mutants, using thymidine analogues 1-3 (Figure 1) as substrates. Wild-type KOD DNA polymerase (Toyobo), KOD Dash DNA polymerase (Toyobo), and Vent(exo-) DNA polymerase (New England Biolabs) were also used as reference materials; Vent(exo-) is a genetically engineered form of the native DNA polymerase, which also belongs to family B, from Thermococcus litoralis [31, 32].

Figure 1. Chemical structures of the thymidine 5'-triphosphate analogues used in this experiment.

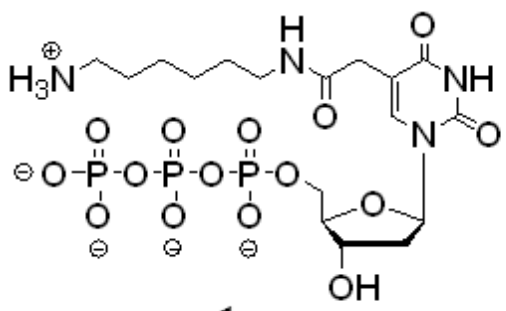

1

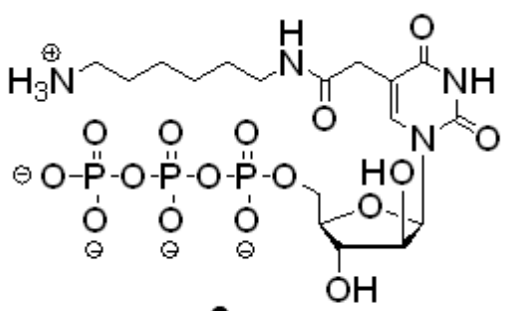

2

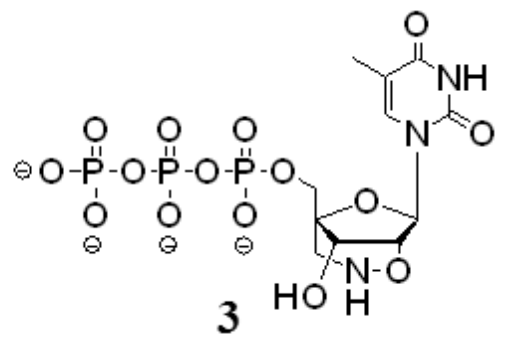




\section{Results and Discussion}

First, we performed modified nucleotide standing-start experiments under conditions that achieve a single completed hit using template DNA T1 (5'- CCG AAT AAA GGT ATG GCC TGT TCG CTA ATC C -3') and 5'-(6-FAM)-labelled primer P1 (5'- GGA TTA GCG AAC AGG CCA TAC CTT -3'). Four KOD mutants $(K O D 1-3,8)$ and Vent(exo-) DNA polymerase were used as the enzyme, and thymidine analogues 1 and 2, thymidine-5'-triphosphate (TTP) and 2'-deoxycytidine-5'-triphospate (dCTP), were used as the substrates. The reaction was performed at $40^{\circ} \mathrm{C}$ because the reactions proceeded too fast to be monitored at the optimal temperature of the enzyme $\left(\sim 75^{\circ} \mathrm{C}\right)$ [33]. All reactions were performed under the same enzyme concentration of $0.0125 \mathrm{U} / \mu \mathrm{L}$. The apparent values for $K_{\mathrm{m}}$ and $V_{\max }$ were obtained from the initial velocities of the primer extension reactions, and then the apparent insertion efficiency $\left(V_{\max } / K_{\mathrm{m}}\right)$ of each substrate triphosphate usage was calculated. The relative apparent insertion efficiency (accuracy) was defined as the ratio of modified analogue insertion to TTP correct insertion efficiencies $\left(V_{\max } / K_{\mathrm{m}}\right)_{\text {analogue }} /\left(V_{\max } / K_{\mathrm{m}}\right)_{\mathrm{TTP}}$, or that of $\mathrm{dCTP}$ misinsertion to TTP correct insertion efficiencies $\left(V_{\max } / K_{\mathrm{m}}\right)_{\mathrm{dCTP}} /\left(V_{\max } / K_{\mathrm{m}}\right)_{\mathrm{TTP}}$ as shown in Table 1 .

Table 1. Modified/natural nucleotide incorporation in primer extension reaction using $K O D$ mutants and Vent(exo-) DNA polymerase. ${ }^{a}$

\begin{tabular}{|c|c|c|c|c|c|}
\hline $\begin{array}{c}\text { DNA } \\
\text { polymerase }\end{array}$ & dNTP & $\begin{array}{c}V_{\max } \\
\left(\min ^{-1}\right)\end{array}$ & $\begin{array}{c}K_{\mathrm{m}} \\
(\mathrm{mM})\end{array}$ & $\begin{array}{c}\text { Insertion efficiency } \\
\qquad V_{\max } / K_{\mathrm{m}}\end{array}$ & Accuracy $^{b}$ \\
\hline \multirow[t]{4}{*}{$K O D 1$} & $\mathrm{~T}$ & 1.8 & 0.021 & 88 & 1 \\
\hline & 1 & 11 & 0.14 & 81 & 0.92 \\
\hline & 2 & 0.10 & 0.26 & 3.8 & 0.043 \\
\hline & $\mathrm{C}$ & 0.074 & 0.66 & 0.11 & 0.0013 \\
\hline \multirow[t]{4}{*}{ KOD2 } & $\mathrm{T}$ & 2.1 & 0.035 & 60 & 1 \\
\hline & 1 & 4.0 & 0.083 & 48 & 0.80 \\
\hline & 2 & 0.32 & 0.099 & 3.3 & 0.055 \\
\hline & $\mathrm{C}$ & 0.019 & 0.11 & 0.17 & 0.0029 \\
\hline \multirow[t]{4}{*}{ KOD3 } & $\mathrm{T}$ & 2.3 & 0.047 & 49 & 1 \\
\hline & 1 & 4.4 & 0.081 & 55 & 1.1 \\
\hline & 2 & 0.27 & 0.099 & 2.7 & 0.055 \\
\hline & $\mathrm{C}$ & 0.033 & 0.70 & 0.048 & 0.00097 \\
\hline \multirow[t]{4}{*}{ KOD8 } & $\mathrm{T}$ & 9.5 & 0.063 & 150 & 1 \\
\hline & 1 & 53 & 0.31 & 170 & 1.1 \\
\hline & 2 & 2.4 & 0.38 & 6.3 & 0.041 \\
\hline & $\mathrm{C}$ & 0.11 & 1.0 & 0.11 & 0.00073 \\
\hline \multirow[t]{4}{*}{ Vent(exo-) } & $\mathrm{T}$ & 0.34 & 0.0030 & 110 & 1 \\
\hline & 1 & 0.29 & 0.0027 & 110 & 0.95 \\
\hline & 2 & 0.049 & 0.0044 & 11 & 0.099 \\
\hline & $\mathrm{C}$ & 0.14 & 1.7 & 0.083 & 0.00073 \\
\hline
\end{tabular}

${ }^{a}$ Experimental conditions are described in Experimental Section. ${ }^{b}$ The initial rate relative apparent insertion efficiency (accuracy); $\left(V_{\max } / K_{\mathrm{m}}\right)_{\text {analogue }} /\left(V_{\max } / K_{\mathrm{m}}\right)_{\mathrm{TTP}}$ and $\left(V_{\max } / K_{\mathrm{m}}\right)_{\mathrm{dCTP}} /\left(V_{\max } / K_{\mathrm{m}}\right)_{\mathrm{TTP}}$. 
In incorporation of thymidine analogues $\mathbf{1}$ and 2, all $K O D$ mutants used showed apparent $K_{\mathrm{m}}$ values larger than that for natural TTP; those values were about 1.7- to 6.4-fold in the cases of the basemodified analogue 1, and were about 2.1- to 13-fold in the cases of the base- and sugar-modified analogue 2. On the other hand, Vent(exo-) DNA polymerase showed $K_{\mathrm{m}}$ values for those two analogues that were almost same as that for TTP. In misincorporation of dCTP, apparent $K_{\mathrm{m}}$ values of $K O D$ mutants were only 3.2- to 32-fold larger than that for TTP as a correct incorporation substrate, while that of Vent(exo-) was about 580-fold larger than that for TTP. However, relative insertion efficiency (accuracy), in other words, substrate specificity of polymerase of when insertion of thymidine nucleotide is the correct incorporation, were almost the same between KOD mutants and Vent(exo-) DNA polymerase. This is because $K O D$ mutants provide larger $K_{\mathrm{m}}$ and $V_{\max }$ in the cases of analogue incorporation, and smaller $K_{\mathrm{m}}$ and $V_{\max }$ in the cases of the misincorporation, compared with Vent(exo-) DNA polymerase. As a result, only slight differences in the ratios of $K_{\mathrm{m}}$ to $V_{\max }$ were seen between $K O D$ mutants and Vent(exo-) DNA polymerase. This catalytic property of $K O D$ mutants would be favourable for enzymatic production of artificial nucleic acids, that is, large $V_{\max }$ values of $K O D$ mutants in analogue incorporation per misincorporation indicate that the reaction of analogue incorporation could progress much faster than that of dCTP misincorporation under sufficiently high substrate concentrations.

We then investigated successive incorporations of modified nucleotide by primer extension reactions using bridged nucleotide 3 , because bridged/locked nucleic acids (BNA/LNAs) would be promising candidates for nucleic acid drugs [34, 35]. We have previously reported [36] that incorporation of this type of bridged nucleotide $\left(2^{\prime}, 4^{\prime}-\mathrm{BNA}^{\mathrm{NC}}\right)$ [37] is more difficult than that of the prototype 2'-O,4'-C-methylene bridged/locked nucleotide (BNA/LNA), which can be incorporated successively using wild-type $K O D$ DNA polymerase [23]. However, 2',4'-BNA ${ }^{\mathrm{NC}}$-type nucleotides possess excellent nuclease resistance much superior to the prototype [38, 39]; therefore, its applications in random screening of nucleic acid enzymes and aptamers, which would require efficient enzymatic incorporation of modified nucleotides, are highly anticipated. In this experiment, template DNA T2 (5'- CCG AAA AAA GGT ATG GCC TGT TCG CTA ATC C -3'), 5'-(6-FAM)-labeled primer P2 (5'- GGA TTA GCG AAC AGG CCA TAC CTT T -3') and eight KOD mutants (KOD1-8) and Vent(exo-) DNA polymerase were used.

As shown in Figure 2, wild-type KOD DNA polymerase, KOD4, KOD5 and KOD7 exhibited the strong 3',5' exonuclease activity [40], and did not provide any elongated products, while the other polymerases provided some elongated products. Among these, KOD8 mainly provided a longer elongated product; it would be four-successive incorporations although three-successive incorporated products must be provided as the full-length product under the condition using those materials. This may have occurred because of DNA template slippage caused by conformation of DNA/BNA helix different from the natural DNA/DNA helix between primer and template strands [41]. Note that the efficient multiple-successive incorporation of bridged analogue 3 under severe conditions such as without any additives, e.g. manganese chloride and betaine [42, 43], could be made by one of KOD mutants assessed, KOD8. 
Figure 2. Successive incorporation of $2^{\prime}, 4^{\prime}$-bridged nucleotides using analogue 3 with various DNA polymerases; KOD Dash (lane 2), wild type $K O D$ (lane 3), KOD1 (lane 4), KOD2 (lane 5), KOD3 (lane 6), KOD4 (lane 7), KOD5 (lane 8), KOD6 (lane 9), KOD7 (lane 10), KOD8 (lane 11), and Vent(exo-) (lane 12). Primer extension reactions were performed for $1 \mathrm{~h}$ at $74^{\circ} \mathrm{C}$ under enzyme concentration of $0.4 \mathrm{U} / \mu \mathrm{L}$. Primer P2 only migrated in lane 1.

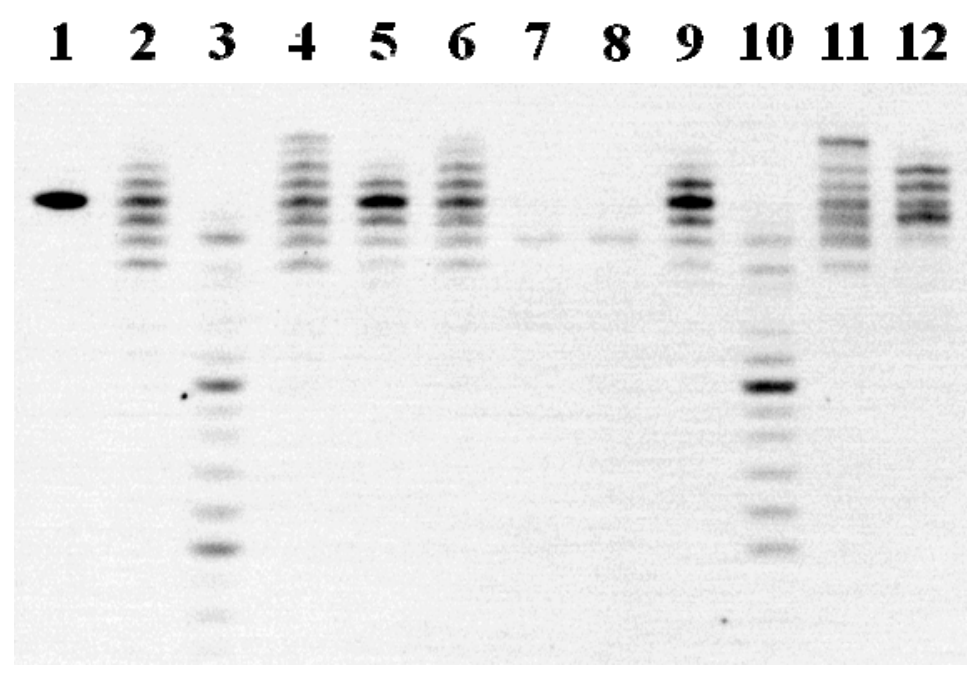

\section{Experimental}

\subsection{Synthesis of modified nucleoside triphosphate analogs and their intermediates}

The modified nucleoside triphosphates $\mathbf{1}$ and $\mathbf{3}$ were synthesized according to our previous reports $[16,36]$. The synthetic routes of the modified nucleoside triphosphate 2 and its intermediates are shown in Scheme 1. NMR Spectra were recorded on a JEOL JNM-AL300 FT-NMR spectrometer. Mass spectral analysis for nucleoside analogues was accomplished on an MDS-Sciex API-100 spectrometer (Applied Biosystems) under atmospheric pressure ionization conditions. Thin-layer chromatography was performed using silica gel $60 \quad \mathrm{~F}_{254}$ plates (Merck). Reversed-phase highperformance liquid chromatography (HPLC) was performed using a JASCO Gulliver system with UV detection at $260 \mathrm{~nm}$ and a packed Wakosil $5 \mathrm{C} 18(\phi 4.6 \times 250 \mathrm{~mm}$; Wako) or TSKgel ODS-80Ts $(\phi 20 \times 250 \mathrm{~mm}$; Tosoh) column. Silica gel 60 (Kanto Chemical; 40-50 $\mu \mathrm{m})$ was used for normalphase column chromatography, and Wakosil 40C18 (Wako) was used for reversed-phase column chromatography. Reversed-phase medium-pressure liquid chromatography (MPLC) was performed using an YFLC-Wprep system (Yamazen) with a glass column $(\phi 33 \times 250 \mathrm{~mm})$ filled with Wakosil 40C18 (Wako). Ion exchange column chromatography was performed using an ECONO system (BioRad) with a glass column $(\phi 25 \times 500 \mathrm{~mm})$ filled with diethylaminoethyl (DEAE) A-25-Sephadex (Amersham Biosciences). 
Scheme 1. Synthesis of thymidine analogue 2.

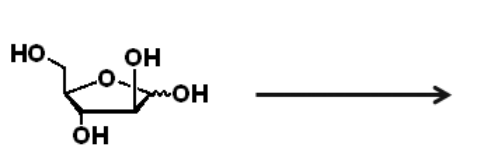

D-Arabinose

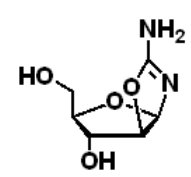

Arabinoaminooxazoline
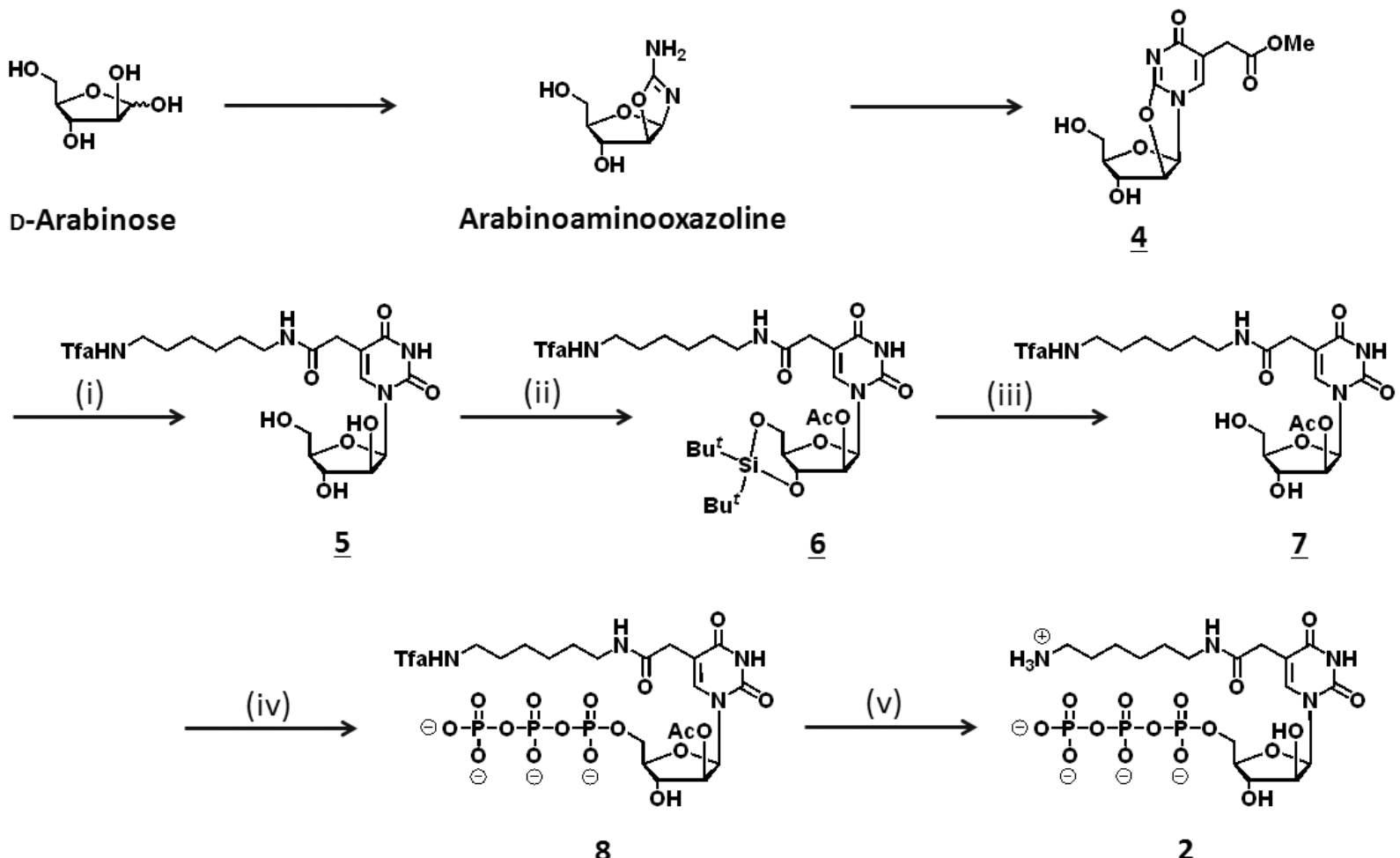

8

$\underline{2}$

Reagents and Conditions: (i) hexamethylenediamine, DMAP, $50^{\circ} \mathrm{C}, 1 \mathrm{~h} ; 2 \mathrm{~N} \mathrm{NaOH}$ aq., r.t., $36 \mathrm{~h}$; trifluoroacetic acid ethylester, TEA, $18 \mathrm{~h}$; (ii) di-tert-butylsilyl-bis(trifluoro- methanesulfonate), DMF, $0{ }^{\circ} \mathrm{C}, 1 \mathrm{~h}$; imidazole, r.t., $1 \mathrm{~h}$; pyridine, acetic anhydride, r.t., $1 \mathrm{~h}$; (iii) pyridinium poly(hydrogenfluoride), r.t., overnight; (iv) $\mathrm{POCl}_{3}, N, N, N^{\prime}, N^{\prime}$-tetramethyl-1,8-naphthalendiamine, trimethyl phosphate, $0^{\circ} \mathrm{C}, 45 \mathrm{~min} ; n$-tributylamine pyrophosphate, DMF, r.t., 1 h; (v) $4 \mathrm{~N} \mathrm{NH}_{4} \mathrm{OH}$ aq., r.t., $2 \mathrm{~h}$.

Nucleoside 5 was synthesized as follows: dimethylaminopyridine (118 mg; $0.97 \mathrm{mmol} ; 0.1 \mathrm{eq})$ and hexamethylenediamine $(5.0 \mathrm{~g} ; 97.0 \mathrm{mmol} ; 10 \mathrm{eq})$ were added to a stirred solution of nucleoside 4 [44] $(2.9 \mathrm{~g} ; 9.7 \mathrm{mmol})$ in dry methanol $(40 \mathrm{~mL})$. The reaction mixture was stirred overnight at $50^{\circ} \mathrm{C}$. After evaporation, the residue was dissolved in methanol $(10 \mathrm{~mL}), 2 \mathrm{~N} \mathrm{NaOH}$ aq. $(25 \mathrm{~mL})$ was added, and the mixture was stirred. After $36 \mathrm{~h}$, the reaction mixture was neutralized with aq. $2 \mathrm{~N} \mathrm{HCl}$. After evaporation, the residue was dissolved in dry methanol $(50 \mathrm{~mL})$, and then trifluoroacetic acid ethyl ester $(13.8 \mathrm{mg} ; 97.0 \mathrm{mmol} ; 10.0 \mathrm{eq})$ and triethylamine $(7.4 \mathrm{mg} ; 72.8 \mathrm{mmol} ; 7.5 \mathrm{eq})$ were added dropwise, and the mixture was stirred for $18 \mathrm{~h}$. After evaporation, the residue was purified by flash column chromatography on silica gel eluting with $5 \%$ to $15 \%$ methanol in chloroform. To remove the excess triethylamine, the residue was purified by reversed-phase MPLC with a linear gradient of $0 \%$ to $50 \%$ methanol in $0.1 \%$ trifluoroacetic acid aq. to give the nucleoside 5 (1.075 g; 23\%): Positive ion ES-MS $m / z$ [assignment] $519.3\left[(\mathrm{M}+\mathrm{Na})^{+}\right], 535.3\left[(\mathrm{M}+\mathrm{K})^{+}\right] ;{ }^{1} \mathrm{H}-\mathrm{NMR}\left(300 \mathrm{MHz}, \mathrm{CDCl}_{3}\right) \delta 7.81(\mathrm{~s}$, $1 \mathrm{H}), 6.13(\mathrm{~d}, 1 \mathrm{H}), 4.87(\mathrm{~s}, 2 \mathrm{H}), 4.58(\mathrm{~s}, 1 \mathrm{H}), 4.18(\mathrm{t}, 1 \mathrm{H}), 4.07(\mathrm{t}, 1 \mathrm{H}), 3.90(\mathrm{~m}, 1 \mathrm{H}), 3.81(\mathrm{t}, 1 \mathrm{H}), 3.14$ $(\mathrm{m}, 4 \mathrm{H}), 1.54(\mathrm{~m}, 4 \mathrm{H}), 1.34(\mathrm{~m}, 4 \mathrm{H}) ;{ }^{1} \mathrm{H}-\mathrm{NMR}\left(300 \mathrm{MHz}, \mathrm{CD}_{3} \mathrm{OD}\right) \delta 7.81\left(\mathrm{~s}, 1 \mathrm{H}, \mathrm{C}_{6} H\right), 6.13(\mathrm{~d}, \mathrm{~J}=$ $\left.4.5 \mathrm{~Hz}, 1 \mathrm{H}, \mathrm{C}_{1^{\prime}} H\right), 4.16\left(\mathrm{~m}, 1 \mathrm{H}, \mathrm{C}_{2^{\prime}} H\right), 4.07\left(\mathrm{~m}, 1 \mathrm{H}, \mathrm{C}_{3^{\prime}} H\right), 3.91\left(\mathrm{~m}, 1 \mathrm{H}, \mathrm{C}_{4^{\prime}} H\right), 3.80\left(\mathrm{~m}, 2 \mathrm{H}, \mathrm{C}_{5^{\prime}} H_{2}\right)$, $3.29\left(\mathrm{~m}, 2 \mathrm{H}, \mathrm{C}_{5} \mathrm{H}_{2}\right), 3.19\left(\mathrm{~m}, 4 \mathrm{H}, \mathrm{C}(=\mathrm{O}) \mathrm{NHCH}_{2}\left(\mathrm{CH}_{2}\right)_{4} \mathrm{CH}_{2} \mathrm{NHTfa}\right), 1.55\left(\mathrm{~m}, 4 \mathrm{H}, \mathrm{C}(=\mathrm{O}) \mathrm{NHCH}_{2} \mathrm{CH}_{2}\right.$ $\left.\left(\mathrm{CH}_{2}\right)_{2} \mathrm{CH}_{2} \mathrm{CH}_{2} \mathrm{NHTfa}\right), 1.35\left(\mathrm{~m}, 4 \mathrm{H}, \mathrm{C}(=\mathrm{O}) \mathrm{NH}\left(\mathrm{CH}_{2}\right)_{2}\left(\mathrm{CH}_{2}\right)_{2}\left(\mathrm{CH}_{2}\right)_{2} \mathrm{NHTfa}\right)$. 
Nucleoside 6 was synthesized as follows: nucleoside 5 (1.075 g; $2.2 \mathrm{mmol})$ was dried in a flask under vacuum overnight. Dry $N, N$-dimethylformamide $(20 \mathrm{~mL})$ was added to the flask under argon, and the solution was cooled to $0^{\circ} \mathrm{C}$. Then, di-tert-butylsilyl-bis(trifluoromethanesulfonate) $(0.77 \mathrm{~mL}$; $2.4 \mathrm{mmol} ; 1.1 \mathrm{eq})$ was added, and the mixture was stirred at $0^{\circ} \mathrm{C}$ for $1 \mathrm{~h}$. Imidazole $(750 \mathrm{mg}$; $11.0 \mathrm{mmol} ; 5.0 \mathrm{eq})$ was added to the reaction mixture and stirred at room temperature for $1 \mathrm{~h}$. Pyridine $(3.0 \mathrm{~mL})$ and acetic anhydride $(1.67 \mathrm{~mL} ; 17.6 \mathrm{mmol} ; 8.0 \mathrm{eq})$ were then added, and stirred for $1 \mathrm{~h}$. After evaporation, the residue was dissolved in dichloromethane and washed with water. The organic layer was dried over $\mathrm{MgSO}_{4}$, filtered, and concentrated in vacuo. Flash column chromatography on silica gel eluting with acetic ether afforded the nucleoside 6 (785 mg, 53\%): Positive ion ES-MS $\mathrm{m} / \mathrm{z}$ [assignment] $701.4\left[(\mathrm{M}+\mathrm{Na})^{+}\right] ;{ }^{1} \mathrm{H}-\mathrm{NMR}\left(300 \mathrm{MHz}, \mathrm{CDCl}_{3}\right) \delta 7.58(\mathrm{~s}, 1 \mathrm{H}), 6.45(\mathrm{~s}, 1 \mathrm{H}), 5.28(\mathrm{t}, 1 \mathrm{H})$, $4.44(\mathrm{q}, 1 \mathrm{H}), 4.22(\mathrm{~m}, 1 \mathrm{H}), 4.07$ (q, 2H), $3.35(\mathrm{~m}, 1 \mathrm{H}), 3.35$ (q, 1H), 3.20 (q, 4H), 2.04 (s, 3H), 1.49 (t, 4H), $1.35(\mathrm{t}, 4 \mathrm{H}), 1.00(\mathrm{~s}, 18 \mathrm{H}) .{ }^{1} \mathrm{H}-\mathrm{NMR}\left(300 \mathrm{MHz}, \mathrm{CDCl}_{3}\right) \delta 7.23\left(\mathrm{~s}, 1 \mathrm{H}, \mathrm{C}_{6} H\right), 6.45\left(\mathrm{~d}, 1 \mathrm{H}, \mathrm{C}_{1}{ }^{\prime} H\right)$, $5.25\left(\mathrm{t}, 1 \mathrm{H}, \mathrm{C}_{2^{\prime}} H\right), 4.43\left(\mathrm{q}, 1 \mathrm{H}, \mathrm{C}_{3^{\prime}} H\right), 4.08\left(\mathrm{~m}, 2 \mathrm{H}, \mathrm{C}_{5^{\prime}} H_{2}\right), 3.71\left(\mathrm{~m}, 1 \mathrm{H}, \mathrm{C}_{4^{\prime}} H\right), 3.34\left(\mathrm{~m}, 2 \mathrm{H}, \mathrm{C}_{5} H_{2}\right)$, $3.19\left(\mathrm{~m}, 4 \mathrm{H}, \mathrm{C}(=\mathrm{O}) \mathrm{NHCH}_{2}\left(\mathrm{CH}_{2}\right)_{4} \mathrm{CH}_{2} \mathrm{NHTfa}\right), 2.04 \quad\left(\mathrm{~s}, \quad 3 \mathrm{H}, \quad \mathrm{OC}(=\mathrm{O}) \mathrm{CH}_{3}\right), 1.53 \quad(\mathrm{~m}, 4 \mathrm{H}$, $\left.\mathrm{C}(=\mathrm{O}) \mathrm{NHCH}_{2} \mathrm{CH}_{2}\left(\mathrm{CH}_{2}\right)_{2} \mathrm{CH}_{2} \mathrm{CH}_{2} \mathrm{NHTfa}\right), 1.33\left(\mathrm{~m}, 4 \mathrm{H}, \mathrm{C}(=\mathrm{O}) \mathrm{NH}\left(\mathrm{CH}_{2}\right)_{2}\left(\mathrm{CH}_{2}\right)_{2}\left(\mathrm{CH}_{2}\right)_{2} \mathrm{NHTfa}\right), 1.10$ $\left(\mathrm{s}, 9 \mathrm{H}, \mathrm{Si}\left(B u^{t}\right)_{2}\right), 1.01\left(\mathrm{~s}, 9 \mathrm{H}, \mathrm{Si}\left(B u^{t}\right)_{2}\right)$.

Nucleoside 7 was synthesized as follows: nucleoside 6 (785 mg; $1.16 \mathrm{mmol}$ ) was dried in a flask under vacuum overnight. Dry dichloromethane $(10.8 \mathrm{~mL})$ was added to the flask under argon, and dry pyridine $(2.16 \mathrm{~mL})$ and pyridinium poly(hydrogenfluoride) $(360 \mu \mathrm{L})$ were added, and the reaction mixture was stirred at room temperature for overnight. After evaporation, the residue washed with diethyl ether, and then purified by flash column chromatography on silica gel eluting with 95:5 dichloromethane-methanol to give the nucleoside 7 (432 mg; 69\%): Positive ion ES-MS $\mathrm{m} / \mathrm{z}$ [assignment] $561.3\left[(\mathrm{M}+\mathrm{Na})^{+}\right]$; ${ }^{1} \mathrm{H}-\mathrm{NMR}\left(300 \mathrm{MHz}, \mathrm{CD}_{3} \mathrm{OD}\right) \delta 7.79\left(\mathrm{~s}, 1 \mathrm{H}, \mathrm{C}_{6} H\right), 6.26(\mathrm{~d}, \mathrm{~J}=4.9 \mathrm{~Hz}$, $\left.1 \mathrm{H}, \mathrm{C}_{1^{\prime}} H\right), 5.26\left(\mathrm{~m}, 1 \mathrm{H}, \mathrm{C}_{2} \cdot H\right), 4.25\left(\mathrm{~m}, 1 \mathrm{H}, \mathrm{C}_{3^{\prime}} H\right), 3.89\left(\mathrm{~m}, 1 \mathrm{H}, \mathrm{C}_{4} \cdot H\right), 3.84\left(\mathrm{~m}, 2 \mathrm{H}, \mathrm{C}_{5^{\prime}} H_{2}\right), 3.29(\mathrm{~m}$, $\left.2 \mathrm{H}, \mathrm{C}_{5} \mathrm{H}_{2}\right), 3.18\left(\mathrm{~m}, 4 \mathrm{H}, \mathrm{C}(=\mathrm{O}) \mathrm{NHCH}_{2}\left(\mathrm{CH}_{2}\right)_{4} \mathrm{CH}_{2} \mathrm{NHTfa}\right), 2.01\left(\mathrm{~s}, 3 \mathrm{H}, \mathrm{OC}(=\mathrm{O}) \mathrm{CH}_{3}\right), 1.54(\mathrm{~m}, 4 \mathrm{H}$, $\left.\mathrm{C}(=\mathrm{O}) \mathrm{NHCH}_{2} \mathrm{CH}_{2}\left(\mathrm{CH}_{2}\right)_{2} \mathrm{CH}_{2} \mathrm{CH}_{2} \mathrm{NHTfa}\right), 1.35\left(\mathrm{~m}, 4 \mathrm{H}, \mathrm{C}(=\mathrm{O}) \mathrm{NH}\left(\mathrm{CH}_{2}\right)_{2}\left(\mathrm{CH}_{2}\right)_{2}\left(\mathrm{CH}_{2}\right)_{2} \mathrm{NHTfa}\right)$.

Nucleoside triphosphate 8 was synthesized as follows: nucleoside 7 (106 mg; $0.2 \mathrm{mmol})$ and $N, N, N^{\prime}, N^{\prime}$-tetramethyl-1,8-naphthalenediamine (Proton Sponge ${ }^{\circledR} ; 64 \mathrm{mg} ; 0.3 \mathrm{mmol} ; 1.5 \mathrm{eq}$ ) were dried in a flask under vacuum overnight. Trimethyl phosphate $(1.5 \mathrm{~mL})$ was added to the flask under argon, and the solution was cooled to $0^{\circ} \mathrm{C}$. Distilled phosphorus oxychloride $(23 \mu \mathrm{L} ; 0.24 \mathrm{mmol} ; 1.2 \mathrm{eq})$ was then added dropwise using a micro syringe, and the reaction mixture was stirred at $0^{\circ} \mathrm{C}$. After $45 \mathrm{~min}$, $n$-tributylamine $(191 \mu \mathrm{L} ; 0.8 \mathrm{mmol} ; 4.0 \mathrm{eq})$ and $n$-tributylamine pyrophosphate $(2.06 \mathrm{~mL}$ of a $0.5 \mathrm{M}$ solution in DMF, $1.0 \mathrm{mmol}, 5.0 \mathrm{eq}$ ) were added at $0^{\circ} \mathrm{C}$, and the reaction mixture was stirred at room temperature for $1 \mathrm{~h}$, then the reaction was quenched with water. The solvents were removed in vacuo, and the residue was dissolved in water. The product was purified using a Sephadex DEAE A-25 column with a linear gradient of 0.05-1.0 M triethylammonium bicarbonate buffer $(\mathrm{pH} 8)$. Fractions containing 8 were combined and evaporated under reduced pressure, then purified by reversed-phase MPLC with a linear gradient of $0 \%$ to $70 \%$ acetonitrile in $10 \mathrm{mM}$ triethylammonium acetate buffer ( $\mathrm{pH} 7$ ), to remove the excess pyrophosphate. Further purification was performed by reversed-phase HPLC $(\phi 20 \times 250 \mathrm{~mm})$ with a linear gradient of $35 \%$ to $70 \%$ acetonitrile in $50 \mathrm{mM}$ triethylammonium acetate buffer ( $\mathrm{pH} 7)$ to give the nucleoside triphosphate $8(36.7 \mu \mathrm{mol})$ in 19\% yield from 7: Negative ion ES-MS $m / z$ [assignment] $776.8\left[(\mathrm{M}-\mathrm{H})^{-}\right]$ 
Nucleoside triphosphate 2 was synthesized as follows: to a stirred solution of triphosphate 8 (3.7 $\mu \mathrm{mol})$ in water $(1 \mathrm{~mL}), 4 \mathrm{~N} \mathrm{NH}{ }_{4} \mathrm{OH}$ aq. $(1 \mathrm{~mL})$ was added, and the mixture was stirred at room temperature for $2 \mathrm{~h}$. The solvents were removed in vacuo, and the residue was dissolved in water. Purification was performed by reversed-phase HPLC $(\phi 20 \times 250 \mathrm{~mm})$ with a linear gradient of $0 \%$ to $50 \%$ acetonitrile in $50 \mathrm{mM}$ triethylammonium acetate buffer $(\mathrm{pH} 7)$ to give the nucleoside triphosphate $2(1.1 \mu \mathrm{mol})$ in 30\% yield from 8: Negative ion ES-MS $m / z$ [assignment] $639.1\left[(\mathrm{M}-\mathrm{H})^{-}\right]$

\subsection{Preparation of mutated KOD DNA polymerases}

Expression and purification of the $K O D$ mutants used were performed basically according to the literatures $[29,30]$.

\subsection{Single nucleotide incorporation in primer extension reaction using KOD mutants and Vent(exo-) DNA polymerase}

Reaction mixtures $(8 \mu \mathrm{L})$ containing the primer $(\mathrm{P} 1)$ at $0.5 \mu \mathrm{M}$, the template (T1) at $0.625 \mu \mathrm{M}$, one of the thymidine 5'-triphosphates (1,2 or TTP) at $1 \mu \mathrm{M}, 3 \mu \mathrm{M}, 5 \mu \mathrm{M}, 10 \mu \mathrm{M}, 20 \mu \mathrm{M}$ and $30 \mu \mathrm{M}$, or 2'deoxycytidine-5'-triphosphate (dCTP) at $0.1 \mathrm{mM}, 0.3 \mathrm{mM}, 0.5 \mathrm{mM}$ and $1 \mathrm{mM}$, and the reaction buffer supplied with the enzyme (at $1 \times$ concentration) were denatured at $95^{\circ} \mathrm{C}$ for 1 min with the thermal cycler, and then annealed at room temperature for $1 \mathrm{~h}$. Subsequently, $2 \mu \mathrm{L}$ of enzyme solution $(0.125$ $\mathrm{U}$ for Vent(exo-) and $K O D$ mutants $(K O D 1-3,8)$ ) were added to the mixture, and the reaction tube was quickly placed in a thermoregulated bath and incubated at $40^{\circ} \mathrm{C}$ during the reaction. Reactions were monitored at $0,1,3,7,15,25$ and $60 \mathrm{~min}$ in the cases of the thymidine $5^{\prime}$-triphosphates (1, 2 and TTP), also at $0,7,15,30,50,80,120$, and $180 \mathrm{~min}$ in the case of dCTP. After the reactions were started, the reaction tubes were removed from the bath sequentially, and immediately quenched by freezing in liquid nitrogen. The frozen reaction mixtures were then mixed with $40 \mathrm{mM}$ EDTA $(2 \mu \mathrm{L})$ containing $0.1 \%$ bromophenol blue and $7 \mathrm{M}$ urea $(12 \mu \mathrm{L})$ containing $3 \mathrm{mM}$ EDTA, and then were melted into a homogeneous solution by vortexing. The sample solutions were resolved by denaturing PAGE, and gel images were recorded on the imager. The amount of reactant and products was measured from the intensity of each band with excitation at $488 \mathrm{~nm}$ to visualize the 5 -labelled fluorophore. The decrease of the primer ratio (\%) was obtained from band intensities of the primer and its elongated products. The data of the time-dependent decrease were fit to hyperbolic saturation curves by the least squares method using OriginPro ver.8.

\subsection{Successive incorporation of 2',4'-bridged nucleotides using analogue 3 with various DNA polymerases}

Reaction mixtures $(8 \mu \mathrm{L})$ containing the primer (P2) at $0.5 \mu \mathrm{M}$, the template (T2) at $0.625 \mu \mathrm{M}, 2,4$ bridged nucleotide analogue 3 at $200 \mu \mathrm{M}$, and the reaction buffer supplied with the enzyme (at $1 \times$ concentration) were denatured at $95^{\circ} \mathrm{C}$ for 1 min with the thermal cycler and then annealed at room temperature for $1 \mathrm{~h}$. Subsequently, $2 \mu \mathrm{L}$ of enzyme solutions [4 $\mathrm{U}$ for Vent(exo-), KOD Dash, wildtype $K O D$ and $K O D$ mutants $(K O D 1-8)]$ were added to the mixture, and the reaction tube was quickly placed in a thermoregulated bath and incubated at $74^{\circ} \mathrm{C}$ during the reaction at $60 \mathrm{~min}$. After the 
reactions were started, the reaction tubes were removed from the bath, and immediately quenched by freezing in liquid nitrogen. The frozen reaction mixtures were then mixed with $40 \mathrm{mM}$ EDTA $(2 \mu \mathrm{L})$ containing $0.1 \%$ bromophenol blue and $7 \mathrm{M}$ urea $(12 \mu \mathrm{L})$ containing $3 \mathrm{mM}$ EDTA, and then were melted into a homogeneous solution by vortexing. The sample solutions were resolved by denaturing PAGE, and gel images were recorded on the imager. The amount of reactant and products was measured from the intensity of each band with excitation at $488 \mathrm{~nm}$ to visualize the $5^{\prime}$-labelled fluorophore.

\section{Conclusions}

We have found that $K O D$ mutants provide large $V_{\max }$ values in the correct analogue incorporations, but relatively small $V_{\max }$ values in misincorporation; on the other hand, other polymerases such as DNA polymerase $\alpha$ involving Vent(exo-) DNA polymerase could mainly distinguish correct incorporation from misincorporation through differences in the $K_{\mathrm{m}}$ values [45]. This nature of $K O D$ DNA polymerase is considered to enable incorporation of modified nucleotides even with a unique chemical structure like the aforementioned BNA. Thus, catalysts of enzymatic production of artificial nucleic acids with excellent fidelity and tolerance for various chemical modifications will be expected through further improvements based on amino acid sequence of $K O D$ DNA polymerase.

\section{Acknowledgements}

We gratefully acknowledge financial support by a Grant-in-Aid for Scientific Research from the Japan Society for the Promotion of Science (JSPS) and a Grant for Industrial Technology Research from the New Energy and Industrial Technology Development Organization (NEDO) of Japan.

\section{References and Notes}

1. Robertson, D.L.; Joyce, G.F. Selection in vitro of an RNA enzyme that specifically cleaves singlestranded DNA. Nature 1990, 344, 467-468.

2. Ellington, A.E.; Szostak, J.W. In vitro selection of RNA molecules that bind specific ligands. Nature 1990, 346, 818-822.

3. Tuerk, C.; Gold, L. Systematic evolution of ligands by exponential enrichment. Science 1990, 249, 505-510.

4. Kuwahara, M.; Sugimoto, N. Molecular evolution of functional nucleic acids with chemical modifications. Molecules 2010, 15, 5423-5444.

5. Kempeneers, V.; Renders, M.; Froeyen, M.; Herdewijn, P. Investigation of the DNA-dependent cyclohexenyl nucleic acid polymerization and the cyclohexenyl nucleic acid-dependent DNA polymerization. Nucleic Acids Res. 2005, 33, 3828-3836.

6. Horhota, A.; Zou, K.; Ichida, J.K.; Yu, B.; McLaughlin, L.W.; Szostak, J.W.; Chaput, J.C. Kinetic analysis of an efficient DNA-dependent TNA polymerase. J. Am. Chem. Soc. 2005, 127, 7427-7434.

7. Leal, N.A.; Sukeda, M.; Benner, S.A. Dynamic assembly of primers on nucleic acid templates. Nucleic Acids Res. 2006, 34, 4702-4710. 
8. Tsai, C.H.; Chen, J.; Szostak, J.W. Enzymatic synthesis of DNA on glycerol nucleic acid templates without stable duplex formation between product and template. Proc. Natl. Acad. Sci. USA 2007, 104, 14598-14603.

9. Lam, C.; Hipolito, C.; Perrin, D. M. Synthesis and enzymatic incorporation of modified deoxyadenosine triphosphates. Eur. J. Org. Chem. 2008, 29, 4915-4923.

10. Kuwahara, M.; Takeshima, H.; Nagashima, J.; Minezaki, S.; Ozaki, H.; Sawai, H. Transcription and reverse transcription of artificial nucleic acids involving backbone modification by templatedirected DNA polymerase reactions. Bioorg. Med. Chem. 2009, 17, 3782-3788.

11. El-Sagheer, A.H.; Brown, T. Synthesis and polymerase chain reaction amplification of DNA strands containing an unnatural triazole linkage. J. Am. Chem. Soc. 2009, 131, 3958-3964.

12. Weisbrod, S.H.; Marx, A. Novel strategies for the site-specific covalent labelling of nucleic acids. Chem. Commun. 2008, 44, 5675-5685.

13. Hocek, M.; Fojta, M. Cross-coupling reactions of nucleoside triphosphates followed by polymerase incorporation. Construction and applications of base-functionalized nucleic acids. Org. Biomol. Chem. 2008, 6, 2233-2241.

14. Loakes, D.; Holliger, P. Polymerase engineering: towards the encoded synthesis of unnatural biopolymers. Chem. Commun. 2009, 31, 4619-4631.

15. Ikonen, S.; Macícková-Cahová, H.; Pohl, R.; Sanda, M.; Hocek, M. Synthesis of nucleoside and nucleotide conjugates of bile acids, and polymerase construction of bile acid-functionalized DNA. Org. Biomol. Chem. 2010, 8, 1194-1201.

16. Sawai, H.; Ozaki, A.N.; Satoh, F.; Ohbayashi, T.; Masud, M.M.; Ozaki, H. Expansion of structural and functional diversities of DNA using new 5-substituted deoxyuridine derivatives by PCR with superthermophilic KOD Dash DNA polymerase. Chem. Commun. 2001, 24, 2604-2605.

17. Obayashi, T.; Masud, M. M.; Ozaki A. N.; Ozaki, H.; Kuwahara, M.; Sawai, H. Enzymatic synthesis of labeled DNA by PCR using new fluorescent thymidine nucleotide analogue and superthermophilic KOD dash DNA polymerase. Bioorg. Med. Chem. Lett. 2002, 12, 1167-1170.

18. Ohbayashi, T.; Kuwahara, M.; Hasegawa, M.; Kasamatsu, T.; Tamura, T.; Sawai H. Expansion of repertoire of modified DNAs prepared by PCR using KOD Dash DNA polymerase. Org. Biomol. Chem. 2005, 3, 2463-2468.

19. Kuwahara, M.; Hanawa, K.; Ohsawa, K.; Kitagata, R.; Ozaki, H.; Sawai, H. Direct PCR amplification of various modified DNAs having amino acids: convenient preparation of DNA libraries with high-potential activities for in vitro selection. Bioorg. Med. Chem. 2006, 14, 2518-2526.

20. Sawai H.; Nagashima J.; Kuwahara M.; Kitagata R.; Tamura T.; Matsui I. Differences in substrate specificity of C(5)-substituted or C(5)-unsubstituted pyrimidine nucleotides by DNA polymerases from thermophilic bacteria, archaea, and phages. Chem. Biodivers. 2007, 4, 1979-1995.

21. Veedu, R.N.; Vester, B.; Wengel, J. Efficient enzymatic synthesis of LNA-modified DNA duplexes using KOD DNA polymerase. Org. Biomol. Chem. 2009, 7, 1404-1409.

22. Veedu, R. N.; Wengel, J. Locked nucleic acid nucleoside triphosphates and polymerases: on the way towards evolution of LNA aptamers. Mol. Biosyst. 2009, 5, 787-792. 
23. Obika, S.; Nanbu, D.; Hari, Y.; Morio, K.; In, Y.; Ishida, T.; Imanishi, T. Synthesis of 2'-O,4'-Cmethyleneuridine and -cytidine. Novel bicyclic nucleosides having a fixed C3'-endo sugar puckering. Tetrahedron Lett. 1997, 38, 8735-8738.

24. Obika, S.; Nanbu, D.; Hari, Y.; Andoh, J.; Morio, K.; Doi, T.; Imanishi, T. Stability and structural features of the duplexes containing nucleoside analogs with a fixed N-type conformation, 2'-O,4'C-methyleneribonucleosides. Tetrahedron Lett. 1998, 39, 5401-5404.

25. Singh, S. K.; Nielsen, P.; Koshkin, A. A.; Wengel, J. LNA (locked nucleic acids): synthesis and high-affinity nucleic acid recognition. Chem. Commun. 1998, 4, 455-456.

26. Wirges C.T.; Timper J.; Fischler M.; Sologubenko, A. S.; Mayer, J.; Simon U.; Carell, T. Controlled nucleation of DNA metallization. Angew. Chem. Int. Ed. 2009, 48, 219-223.

27. Raindlová, V.; Pohl, R.; Sanda, M.; Hocek, M. Direct polymerase synthesis of reactive aldehydefunctionalized DNA and its conjugation and staining with hydrazines. Angew. Chem. Int. Ed. 2010, 49, 1064-1066.

28. Takagi, M.; Nishioka, M.; Kakihara, H.; Kitabayashi, M.; Inoue, H.; Kawakami, B.; Oka, M.; Imanaka, T. Characterization of DNA polymerase from Pyrococcus sp. strain KOD1 and its application to PCR. Appl. Environ. Microbiol. 1997, 63, 4504-4510.

29. Nishioka, M.; Mizuguchi, H.; Fujiwara, S.; Komatsubara, S.; Kitabayashi, M.; Uemura, H.; Takagi, M.; Imanaka, T. Long and accurate PCR with a mixture of KOD DNA polymerase and its exonuclease deficient mutant enzyme. J. Biotechnol. 2001, 88, 141-149.

30. Kuroita, T.; Matsumura, H.; Yokota, N.; Kitabayashi, M.; Hashimoto, H.; Inoue, T.; Imanaka, T.; Kai, Y. Structural mechanism for coordination of proofreading and polymerase activities in Archaeal DNA polymerases. J. Mol. Biol. 2005, 351, 291-298.

31. Perler, F. B.; Comb, D. G.; Jack, W. E.; Moran, L. S.; Qiang, B.; Kucera, R. B.; Benner, J.; Slatko, B. E.; Nwankwo, D. O.; Hempstead, S. K.; Carlow, C. K. S.; Jannasch, H. Intervening sequences in an Archaea DNA polymerase gene. Proc. Natl. Acad. Sci. USA 1992, 89, 5577-81.

32. Kong, H.; Kucera, R. B.; Jack, W. E. Characterization of a DNA polymerase from the hyperthermophile archaea Thermococcus litoralis. Vent DNA polymerase, steady state kinetics, thermal stability, processivity, strand displacement, and exonuclease activities. J. Biol. Chem. 1993, 268, 1965-1975.

33. Kuwahara, M.; Nagashima, J.; Hasegawa, M.; Tamura, T.; Kitagata, R.; Hanawa, K.; Hososhima, S.; Kasamatsu, T.; Ozaki, H.; Sawai, H. Systematic characterization of 2'-deoxynucleoside- 5'triphosphate analogs as substrates for DNA polymerases by polymerase chain reaction and kinetic studies on enzymatic production of modified DNA. Nucleic Acids Res. 2006, 34, 5383-5394.

34. Lanford, R. E.; Hildebrandt-Eriksen E. S.; Petri, A.; Persson, R.; Lindow, M.; Munk, M. E.; Kauppinen, S.; Ørum, H. Therapeutic silencing of microRNA-122 in primates with chronic hepatitis C virus infection. Science 2010, 327, 198-201.

35. Gupta, N.; Fisker, N.; Asselin, M. C.; Lindholm, M.; Rosenbohm, C.; Ørum, H.; Elmén, J.; Seidah, N. G., Straarup, E. M. A locked nucleic acid antisense oligonucleotide (LNA) silences PCSK9 and enhances LDLR expression in vitro and in vivo. PLoS One 2010, 5, e10682.

36. Kuwahara, M.; Obika, S.; Nagashima, J.; Ohta, Y.; Suto, Y.; Ozaki, H.; Sawai, H.; Imanishi, T. Systematic analysis of enzymatic DNA polymerization using oligo-DNA templates and triphosphate analogs involving 2',4'-bridged nucleosides. Nucleic Acids Res. 2008, 36, 4257-4265. 
37. Rahman, S. M.; Seki, S.; Obika, S.; Haitani, S.; Miyashita, K; Imanishi, T. Highly stable pyrimidine-motif triplex formation at physiological $\mathrm{pH}$ values by a bridged nucleic acid analog. Angew. Chem. Int. Ed. 2007, 46, 4306-4309.

38. Kuwahara, M.; Obika, S.; Takeshima, H.; Hagiwara, Y.; Nagashima, J.; Ozaki, H.; Sawai, H.; Imanishi T. Smart conferring of nuclease resistance to DNA by 3'-end protection using 2',4'bridged nucleoside-5'-triphosphates.Bioorg. Med. Chem. Lett. 2009, 36, 2941-2943.

39. Kasahara, Y.; Kitadume, S.; Morihiro, K.; Kuwahara, M.; Ozaki, H.; Sawai, H.; Imanishi, T.; Obika, S. Effect of 3'-end capping of aptamer with various 2',4'-bridged nucleotides: enzymatic post-modification toward a practical use of polyclonal aptamers. Bioorg. Med. Chem. Lett. 2010, 20, 1626-1629.

40. Creighton, S.; Bloom, L. B.; Goodman, M. F. Gel fidelity assay measuring nucleotide misinsertion, exonucleolytic proofreading, and lesion bypass efficiencies. Methods Enzymol. 1995, $262,232-256$.

41. Rahman, S. M.; Seki, S.; Obika, S.; Yoshikawa, H.; Miyashita, K.; Imanishi, T. Design, synthesis, and properties of $2^{\prime}, 4^{\prime}-\mathrm{BNA}^{\mathrm{NC}}$ : a bridged nucleic acid analogue, J. Am. Chem. Soc. 2008, 130, 4886-4896.

42. Jäger, S.; Rasched, G.; Kornreich-Leshem, H.; Engeser, M.; Thum, O.; Famulok, M. A versatile toolbox for variable DNA functionalization at high density. J. Am. Chem. Soc. 2005, 127, 1507115082.

43. Veedu, R. N.; Vester, B.; Wengel, J. Enzymatic incorporation of LNA nucleotides into DNA strands, ChemBioChem 2007, 8, 490-492.

44. Sawai, H.; Nakamura, A.; Sekiguchi, S.; Yumoto, K.; Endoh, M.; Ozaki, H. Efficient synthesis of new 5-substituted uracil nucleosides useful for linker arm incorporation. J. Chem. Soc., Chem. Comm. 1994, 1997-1998.

45. Mendelman, L. V.; Boosalis, M. S.; Petruska, J.; Goodman, M. F. Nearest neighbor influences on DNA polymerase insertion fidelity. J. Biol. Chem. 1989, 264, 14415-14423.

Sample Availability: The new analog, modified nucleoside triphosphate $\mathbf{2}$ is available free to academic researchers under a Material Transfer Agreement (MTA).

(C) 2010 by the authors; licensee MDPI, Basel, Switzerland. This article is an open access article distributed under the terms and conditions of the Creative Commons Attribution license (http://creativecommons.org/licenses/by/3.0/). 